\title{
Mikrotxantiloien fabrikazioa eta haien aplikazioak biomedikuntzan
}

\author{
(Fabrication of micropatterns and their application in biomedicine) \\ Eider Aldalur, Jose-Ramon Sarasua, Aitor Larrañaga, Jone M. Ugartemendia* \\ Biomaterial Polimerikoen Zientzia eta Ingeniaritza taldea (ZIBIO), \\ Meatze-Metalurgia Ingeniaritza eta Materialen Zientzia saila eta POLYMAT, \\ Bilboko Ingeniaritza Eskola (UPV/EHU)
}

\begin{abstract}
LABURPENA: Azken aldian, biobateragarriak diren eta zelulen itsaspen selektiboa baimentzen duten gainazalak biomedikuntzako zenbait aplikazio ezberdinetarako oso desiragarriak bihurtu dira. Bide horretatik, material biobateragarrietan horrelako gainazalak lortzeko, posible da mikrotxantiloiak (maila mikrometrikoan eginiko gainazaleko formak) erabiltzea; izan ere, horiek substratu zehatz baten gainean zelula-hazkunde kontrolatua eta bideratua baimendu ditzakete. Lan honetan, hain zuzen ere, mikrotxantilioak lortzeko teknikak berrikusten dira, hauek ehun-ingeniaritzan eta biomedikuntzan aurkitzen dituzten aplikazio nagusiak azpimarratuz, hala nola, biosentsoreak, ehun-ingeniaritzarako in vitro eginiko kultibo zelularrak eta inplante gainazal egokiak sortzea. Azkenik, zelulen itsaspen selektiboari dagokionez, gure ikerketa taldean 3D inpresioz sortutako mikrotxantiloi polimerikoen aurre-emaitzak aurkezten dira. Hala, emaitza horietatik ondorioztatu da 3D inpresioa teknika egokia dela mikrotxantiloi zehatzak, errepikakorrak eta egonkorrak fabrikatzeko.
\end{abstract}

HITZ GAKOAK: biomedikuntzarako polimeroak, mikrotxantiloiak, 3D inprimagailua, fabrikazio-gehigarria, itsaspen-selektiboa.

ABSTRACT: The use of biocompatible surfaces that allow selective adhesion of cells has gained tremendous interest in the biomedical field. Micropatterns, defined as surface shapes at the micrometric scale, are introduced as a versatile approach to obtain such surfaces that can promote controlled and directed cell growth in a specific substrate. Here, state of the art techniques found in bibliography to obtain micropatterned surfaces are thoroughly reviewed, together with their main applications in the field of biomedicine and tissue engineering such as biosensors, cell cultures for tissue engineering and/or suitable implant surfaces. Finally, some preliminary results obtained in our research group are presented herein, which highlight the potential of $3 D$ printing to achieve highly precise and accurate polymer micropatterns that promote selective cell adhesion.

KEYWORDS: biomedical polymers, micropatterning, 3D printing, additive manufacturing, selective adhesion.

\footnotetext{
* Harremanetan jartzeko / Corresponding author: Jone M. Ugartemendia. Biomaterial Polimerikoen Zientzia eta Ingeniaritza taldea (ZIBIO), Meatze-Metalurgia Ingeniaritza eta Materialen Zientzia saila eta POLYMAT, Bilboko Ingeniaritza Eskola, UPV/EHU, Ingeniero Torres Quevedo Enparantza 1 (48013 Bilbo-Bizkaia), Euskal Herria. - jone.munoz@ehu.eus https://orcid.org/0000-0002-7158-5371.

Nola aipatu / How to cite: Aldalur, Eider; Sarasua, Jose-Ramon; Larrañaga, Aitor; M. Ugartemendia, Jone (2019). «MikrotxantiIoien fabrikazioa eta haien aplikazioak biomedikuntzan»; Ekaia, 36, 2019, 15-30. (https://doi.org/10.1387/ekaia.20157).

Jasoa: 18 iraila, 2018; Onartua: 7 otsaila, 2019.

ISSN 0214-9001 - elSSN 2444-3255 / ㄷ 2019 UPV/EHU

(c) (i) (-) Obra hau Creative Commons Atribución 4.0 Internacional-en

BY NC SA lizentziapean dago
} 


\section{SARRERA}

Mikrotxantiloiak, definizioz, gainazaletan (2 dimentsiotan) burutzen diren maila mikrometrikoko formak dira, eta albo-neurri gisa nanometroaren eta milimetroaren arteko dimentsioak dituzte (ikus 1. irudia). Horiek, gainazal mota ugaritan eta material mota anitzetan burutu daitezke eta, besteak beste, biomedikuntzako zenbait aplikaziotarako erabiltzen dira [1]. Izan ere, biomedikuntzaren arloan biobateragarriak diren eta zelulen itsaspen-selektiboa baimentzen duten gainazalak oso funtsezkoak dira [1], eta horiek lortu ahal izateko, mikrotxantiloien erabilerak gora egin du azken aldian.

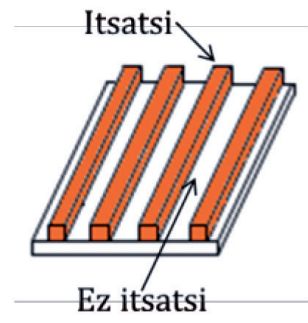

(a)

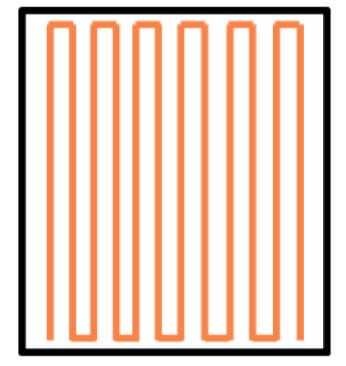

(b)

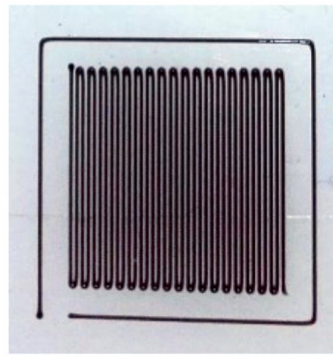

(c)

1. irudia (a-b). Mikrotxantiloien errepresentazio grafikoa. (c) 3D inpresio bidez fabrikatutako silikonazko $0,18 \mathrm{~mm}$-ko elkarren arteko tartea duten zutabe artekatu formako mikrotxantiloiaren itxura erreala.

Horrelako aplikazioetan, txantiloiek gainazala zelulak itsats daitezkeen eta itsats ezin daitezkeen sektoreetan banatzen dute. Hala, behin mikrotxantiloiak sortuta, zelulak bi dimentsioko substratu baten zonalde batzuetan itsatsita geratzen dira, eta zelula gehienek in vivo duten egoera, zelulaz kanpoko matrizean kokatuta egotea, imitatzen saiatzen dira [2]. Gainera, modu horretara, zelula-hazkuntza norabidetua eta zelulen dentsifikazioa ere lor daitezke. Funtsean, gainazalen topografiak, zimurtasuna, poroak eta orientazioa barnean hartuta, baliagarriak dira zelulen portaera, hala nola, itsaspena, orientazioa, mugikortasuna, hazkuntza eta diferentziazioa, kontrolatzeko [3,4]. Hala, mikrotxantiloiak gainazal-ezaugarri hauetaz baliatzen dira zelulen kokapen selektiboa lortzeko.

Modu horretara, maila nanometrikoan zelulen eta gainazalaren arteko interakzioetan eragina duten faktoreak bitan banatu daitezke. Batetik, alderdi fisikoa dago, non substratuaren zurruntasuna, zimurtasuna eta topografiarekin erlazionatutako faktoreak sartzen baitira, eta bestetik, alderdi 
Mikrotxantiloien fabrikazioa eta haien aplikazioak biomedikuntzan

kimikoa, molekula aktiboen mugikortasun-murrizketarekin erlazionatua. Horien artean dira, esaterako, gainazal-karga eta hidrofilitatea (urarekiko afinitatea). Hala, propietate edo faktore horiek manipula daitezke mikrotxantiloien bidez, zelulen distribuzio espaziala substratuaren gainean kontrolatzeko. Esaterako, ikerketa batean fibroblastoak in vitro kultibatu dira, ongi kontrolatutako gainazal topografia duen eta urarekiko afinitate gradienteak dituen polikarbonatozko mintz-porotsu baten gainean eta gainazalaren zati hidrofiloan zelulak itsasten direla ikusi da. Gainera, zati hidrofoboan baino ugaltze handiagoa dute, poroen neurria edozein izanik ere [2]. Bestalde, zenbait ikerketatan maila nanometriko eta mikrometrikoetan geometrikoki ezberdinak diren gainazaleko formak (irloteak, zutabeak, punta zorrotzak, poroak, sareak...) erabili izan dira, zelulen itsastea zeinetan den egokiena ikusteko [5].

Horrekin lotuta, zelulen eta ehunen zahartzea dela eta, oraindik gizakia ez da gai denboraren igaroari aurre egiteko. Hala, gaur egun zahartzeagatik edo lesio batengatik kaltetutako ehunen birsortzea burutzea eta transplantatzeko prest dauden organoak in vivo zein in vitro sortzea medikuntzaren erronka nagusietakoak dira. Hain zuzen ere, horiei erantzuna ematen die ehun-ingeniaritzak [6]. Ehun-ingeniaritza azken urteetan garapen handia izan duen birsortze-medikuntzaren adar multidisziplinarra da. Ehun-ingeniaritzan zelula-euskarriak, zelulak eta biologikoki aktiboak diren molekulak konbinatzen dira ehun funtzionalak lortzeko [6]. Hala, ingeniaritza mota horren helburua egitura funtzionalak lortzea da, ehun kaltetuak edo organo osoak birsortzeko, mantentzeko edo hobetzeko [7]. Gainera, ehun-ingeniaritzak barnean hartzen ditu, besteak beste, ama-zelulen teknologia, faktore biologikoak eta zelula-hazkuntza eta eraldaketarako materialen ezagutza, eta azken horretan mikrotxantiloiek lagundu dezakete [8].

\section{FABRIKAZIO TEKNIKAK}

Gaur egun, material polimerikoen gainean zelulak itsatsiko diren mikrotxantiloi polimerikoak fabrikatzeko teknika mota ezberdinak existitzen dira, bakoitzak dituen abantaila eta desabantailekin. Teknika asko dauden arren, guztiek ezaugarri komun bat dute: zelula-itsaspena baimentzen dute gainazaleko azal desberdinetan txantiloien bidez [9].

1970. urtetik, horrelako mikrotxantiloiak egiteko teknikak garatu egin dira, eta gaur egun, bi taldetan bana daitezke: itsaste-eremuak definitzeko gainazalen kimika erabiltzen dutenak eta muga fisikoen bidez zelulen itsaste-areak mugatzen dituztenak. Teknika ezberdin asko egon arren, gehienek bi dimentsioko gainazaletan sortzen dituzte horrelako areak; izan ere, gainazalaren propietate fisiko eta topografikoek zelulen funtzioetan drastikoki 
eragiten dute [10]. Bestalde, teknika mota aukeratzeko, garrantzitsua da mikrotxantiloiak substratuaren material berean edo material ezberdinetan egingo diren jakitea. Hala, 1. taulan laburbilduta agertzen dira berrikuspen bibliografikoan aurkitu diren eta mikrotxantiloiak substratuaren material ezberdinean sortzen dituzten teknikak. Gainera, teknika horietako bakoitza 2. irudian ikus daiteke eta jarraian laburki azaltzen da (1. taula).

\subsection{Litografia-biguna}

Litografia-biguna gainazaleko egitura kimikoak sortzeko erabiltzen da eta, fotolitografiarekin konparatuta, teknika merkea da, erabiltzen duen ekipamendu urria delako [12]. Talde horren barnean sartzen dira estanpa elastomerikoak egitura kimikoak sortzeko erabiltzen dituzten teknika guztiak eta bi dira garrantzitsuenak: mikrokontaktu-inpresioa (Microcontact Printing; $\mu \mathrm{CP}$ ) eta mikrofluxu bidez mikrotxantiloiak sortzea [15].

\subsubsection{Mikrokontaktuzko inpresioa}

Teknika honetan, lehenik eta behin, 2.(a) irudian ikusten den bezala, siliziozkoa den eta fotolitografia bidez mikroegituratuta dagoen molde batean polimero likidoa ezartzen da polidimetilsiloxanozko (PDMS) estanpa-elastomeriko bat sortzeko. Behin estanpa gogortuta, moldea kendu eta estanparen gainean biomolekulak, proteinak, polimeroak (zelulen itsasgarritasuna hobetzen dute) edo zelula-suspentsioak ezartzen dira [10] eta horiek gainazalera atxikita geratzen dira. Ondoren, substratuaren gainera kasuan kasuko substantzia estanparen formarekin transferitzen da, eta horrela, substratuaren gainean mikrotxantiloiak sortuko dira [15].

\subsubsection{Mikrofluxu bidezkoa}

Kasu honetan (ikus 2.(b) irudia), txantiloiaren forma daraman PDMS-zko estanpa substratuaren gainean ezartzen da, eta mikrokanalak sortzen dira. Ondoren, fluidoa kanal horietan injektatzen da, eta txantiloiaren forma osatzen duten azaleretatik fluxua pasaraztean, nahi den materiala gainazalean ezarrita geratzen da, eta mikrotxantiloiak sortzen dira [14]. 


\begin{tabular}{|c|c|c|c|c|c|}
\hline 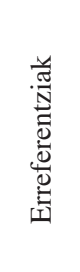 & $\begin{array}{l}\bar{n} \\
\pm \\
\dot{\Xi} \\
a \\
\vdots \\
\Xi \\
\Xi\end{array}$ & $\begin{array}{l}\Xi \\
\Xi \\
\Xi\end{array}$ & $\begin{array}{l}\sigma \\
\stackrel{1}{\Xi} \\
\underline{\Xi}\end{array}$ & $\begin{array}{l}\infty \\
\Xi \\
\Xi\end{array}$ & $\begin{array}{l}\bar{\imath} \\
\stackrel{2}{\Xi}\end{array}$ \\
\hline 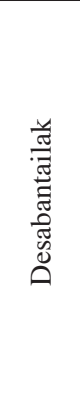 & 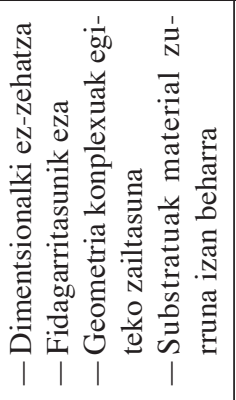 & 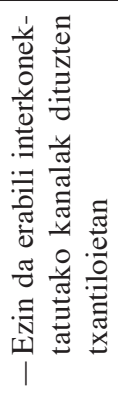 & 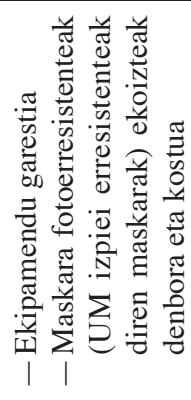 & 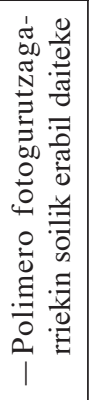 & 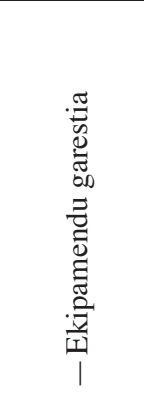 \\
\hline 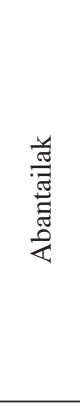 & 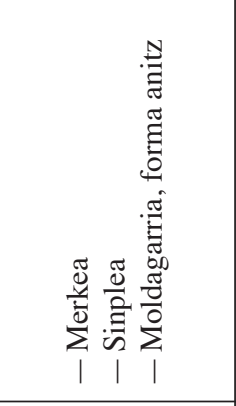 & 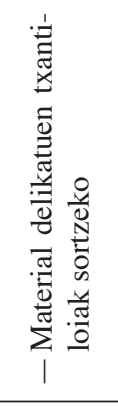 & 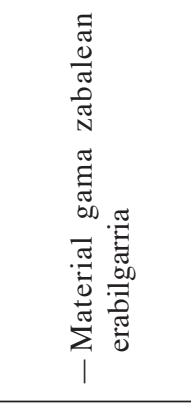 & 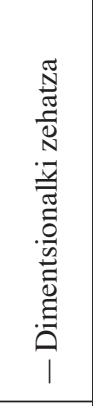 & 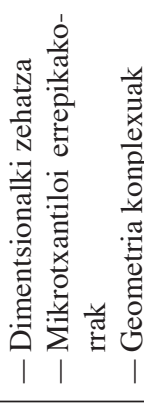 \\
\hline 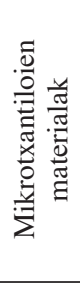 & 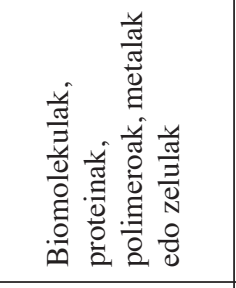 & 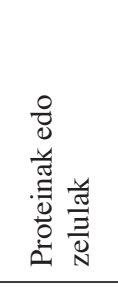 & 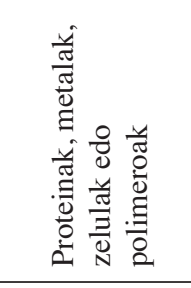 & 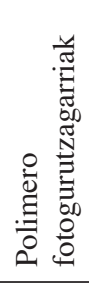 & 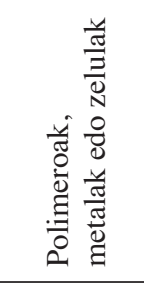 \\
\hline \multirow[t]{2}{*}{ 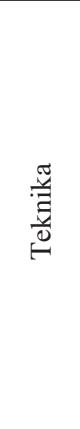 } & 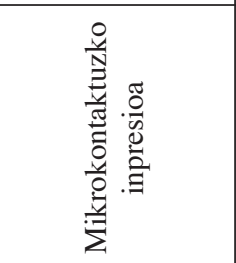 & 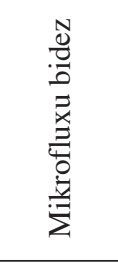 & \multirow[t]{2}{*}{ 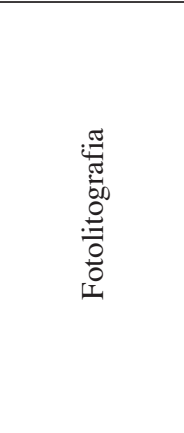 } & \multirow{2}{*}{ 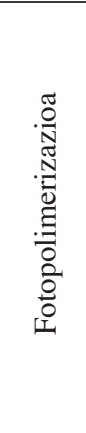 } & \multirow[t]{2}{*}{ 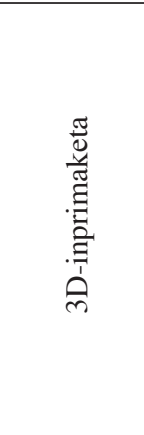 } \\
\hline & \multicolumn{2}{|l|}{ 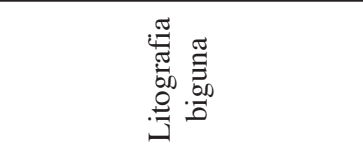 } & & & \\
\hline
\end{tabular}

https://doi.org/10.1387/ekaia.20157 


\subsection{Fotolitografia}

Teknika honen barnean prozedura mota ugari daude, baina guztiek dute ezaugarri komun bat: denek erabiltzen dituzte maskara-fotoerresistente bat eta izpi ultramoreak (UM). Hala, 2.(c) irudian ikusten den adibidean, estalki baten gainean maskara-fotoerresitentea ezartzen da, eta UM izpien bidez estalkian maskarak duen forma bera lortzen da. Modu horretara, substratuaren nahi diren atalak estalkirik gabe geratzen dira, eta besteak estalkiarekin. Ondoren, gainazal osoan nahi den materiala (metalak, proteinak...) depositatzen da. Azkenik, substratutik estalkia kentzen da, eta horrela nahi izan den materialaren txantiloia lortzen da [15].

\subsection{Fotopolimerizazioa}

Kasu honetan (ikus 2.(d) irudia), fotoerresistentea den eta nahi dugun txantiloiaren egitura duen itzal-maskara bat erabiltzen da. Substratuaren gainean interesatzen den polimero fotogurutzagarria ezarri ondoren, maskara-fotoerresistente horren gainean jarri eta UM izpiekin argiztatuko da [18]. Hala, maskararen zati fotoerresistenteetan ez da polimeroaren gurutzaketa gertatuko, eta, aldiz, beste zatietan bai. Horrela, nahi den geometria duen egitura sor daiteke mikrotxantiloi gisa [17].

\subsection{Estrusio bidezko 3D inprimaketa}

Teknologia honetan, inpresio-punta baten bidez, gainazal lauetan, zehaztasun handiz, guk nahi dugun lekuan, nahi dugun material kantitatea depositatzen da. Horrela, mikrotxantiloiak desio den egitura zehatza emanez fabrikatzea lortzen da, nahi den materialean (ikus 2.(e) irudia).

\section{APLIKAZIOAK BIOMEDIKUNTZAN}

Lehenik eta behin, aipatzekoa da mikrotxantiloiak oso erabiliak direla zelulen biologiako oinarrizko ikerketetarako. Izan ere, horien bidez, zelulen kokapen espaziala eta tamaina kontrola daitezke, eta ikusi da zelulen formek eta haien kokapenek nabarmen eragiten dutela banaketan, ugaltzean eta diferentziazioan. Hala, tamaina eta forma ezberdinetako txantiloiek zelula-zelula eta zelula-substratu interakzioak kontrola ditzakete, eta horiek zelulekin erlazionatutako prozesuetan eta zeluletan beretan duten eragina nabarmena da [5]. Beraz, esaterako, mikrotxantiloiak lagungarriak dira terapia zelularra aurrera eramateko; izan ere, hartan, prozedura ezberdinen bidez jatorri ezberdineko ama-zelulak nahi den zelula motatan ezberdintzen edo diferentziatzen dira [21]. 


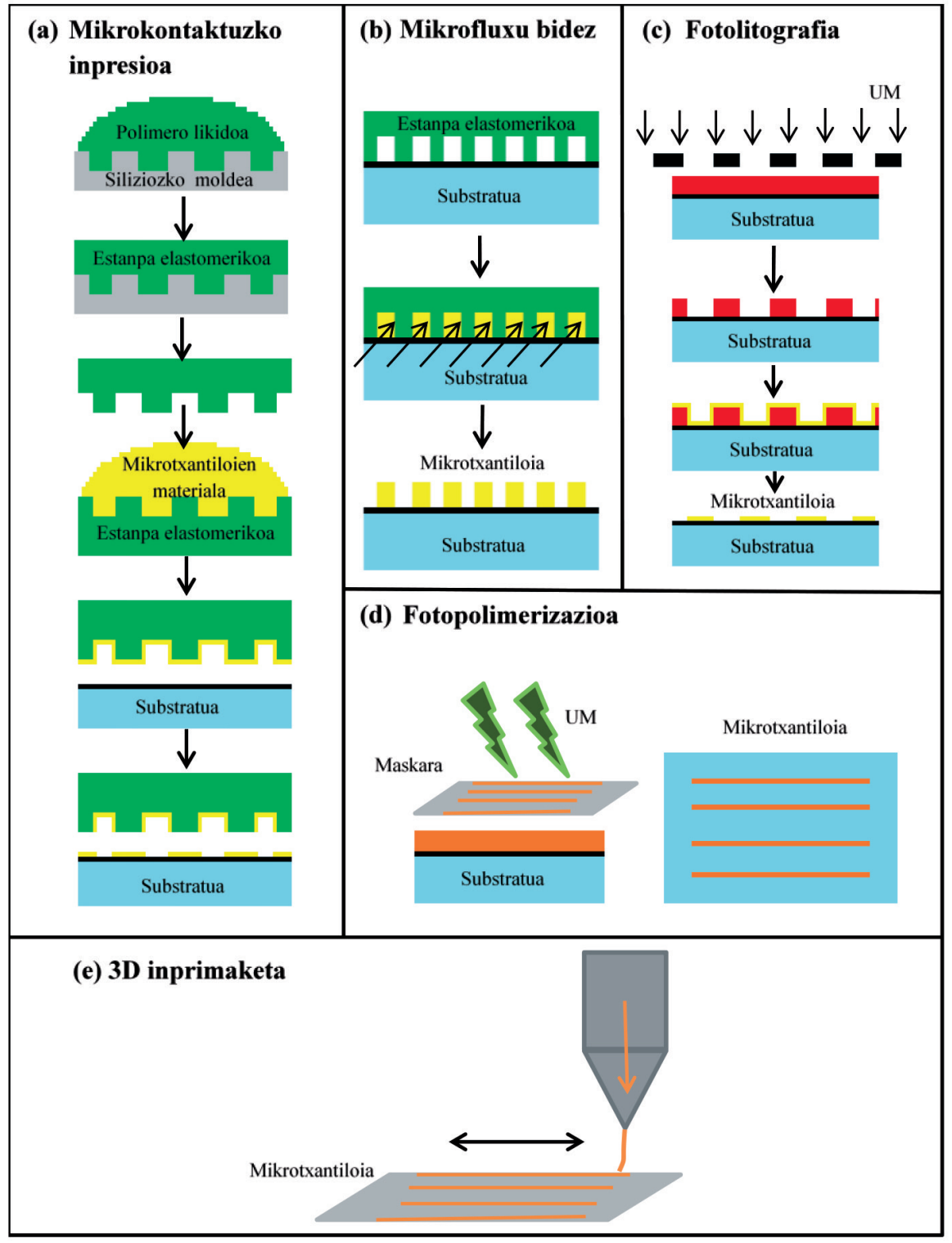

2. irudia. Mikrotxantiloiak sortzeko teknikak: (a) mikrokontaktu-inpresioa, (b) mikrofluxu bidezkoa, (c) fotolitografia, (d) fotopolimerizazioa eta (e) 3D inprimaketa.

Bide horretatik, mikrotxantiloiek zenbait aplikazio biomediko dituzte; garrantzitsuenak ehun-ingeniaritza, inplanteen gainazal egokiak sortzea eta 
zeluletan oinarritutako biosentsoreak dira. Hala, 3. irudian ikus daitezke nerbio-sistemarekin erlazioa duten aplikazio horien zenbait adibide erreal.

\subsection{Ehun-ingeniaritza}

Biomaterialen berezko gainazal-topografia gehienak irregularrak dira, zelulen ausazko antolamendua lortzen dute eta funtzionamendu biologikoan eragina dute. Hala, topografia erregulardun gainazalak dituzten biomaterialak oso beharrezkoak dira zelulen portaera (itsaspena, orientazioa, mugikortasuna, hazkuntza, diferentziazioa...) kontrolatzeko, eta hori dela eta, gainazal mota hori oso egokia da ehunen birsortzea burutzeko [4]. Horrelako gainazalak lortzeko, mikrotxantiloiak sortzeko teknikak erabiltzen dira, eta biomaterialen gainean nahi bezalako egitura erregularrak sortzen dira.

Gainera, ehunak, oro har, ez dira soilik zelula mota beraren metaketa, zelula mota askoz osatuak daude, eta, beraz, zelula-zelula interakzioek garrantzi handia dute zenbait organoren fisiologian; adibidez, gibela, muskuluak eta odol-hodiak. Dena den, teknika tradizionalekin ez da posible substratu berean zelula mota ezberdinak kontrol maila altuarekin ezartzea. Mikrotxantiloiek, ordea, bi edo mota gehiagotako zelulen arteko zelula-zelula interakzioak kontrolatzeko aukera ematen dute, eta substratu berean mota bat baino gehiagoko zelulak ezartzea ahalbidetzen dute [3].

Beraz, esan bezala, gaur egun, mikrotxantiloiek ehun-ingeniaritzan erabilera handia dute, zelulen antolamendu espaziala berebizikoa baita aplikazio horretarako. Jakintza-arlo horretan ohikoena da, zelula-euskarri bat, azken finean, albo-dimentsioan milimetro batzuetako neurria duen mikrotxantiloia hartu eta han ama-zelulak ezartzea. Ondoren, ehun-hazkundearen momentuan, egitura horrek euskarri lana burutu eta hazkuntzan kontrola ezarriko du. Hala, ehunen integrazioa eta birsortzea hobetzeko, zelula-euskarriek ehunen morfologia, egitura eta funtzioa imitatu behar dituzte.

Sarri, egitura horien propietate eta ezaugarriek ehun-ingeniaritzaren arrakasta erabakitzen dute, eta argi dago funtsezkoa dela aplikazio bakoitzerako egitura ezberdina diseinatzea [22]. Beraz, ikusi denez, mikrotxantiloiak funtsezkoak dira zelulen kokapen kontrolatua lortzeko eta ehunak birsortzeko. Adibide gisa, ikerketa batean grafeno fluoratuzko substratuan PDMS-zko zutabe artekatuak inprimatu dira, eta ondoren, han ama-zelula mesenkimalak (MSC) ezarri dira. Ikusi da ama-zelula horiek zutabeen norabidean lerrokatu direla eta markatzaile neuralen (TUJ1, MAP2) kantitatea handitu dela mikroegiturarik gabeko gainazalekin alderatuz. Ondoren, horiek nerbio-sistema periferikoaren birsortzean erabiltzea posible da. Hala, 3.(a) irudian ikus daitezke mikrotxantiloiak sortzeko prozesuaren adierazpen grafikoa, lortu diren mikrotxantiloietan zelulen itxura eta mikrotxantiloiak dituzten eta ez dituzten gainazaletako markatzaile neuralen kantitateen ehunekoen konparaketak [20]. 


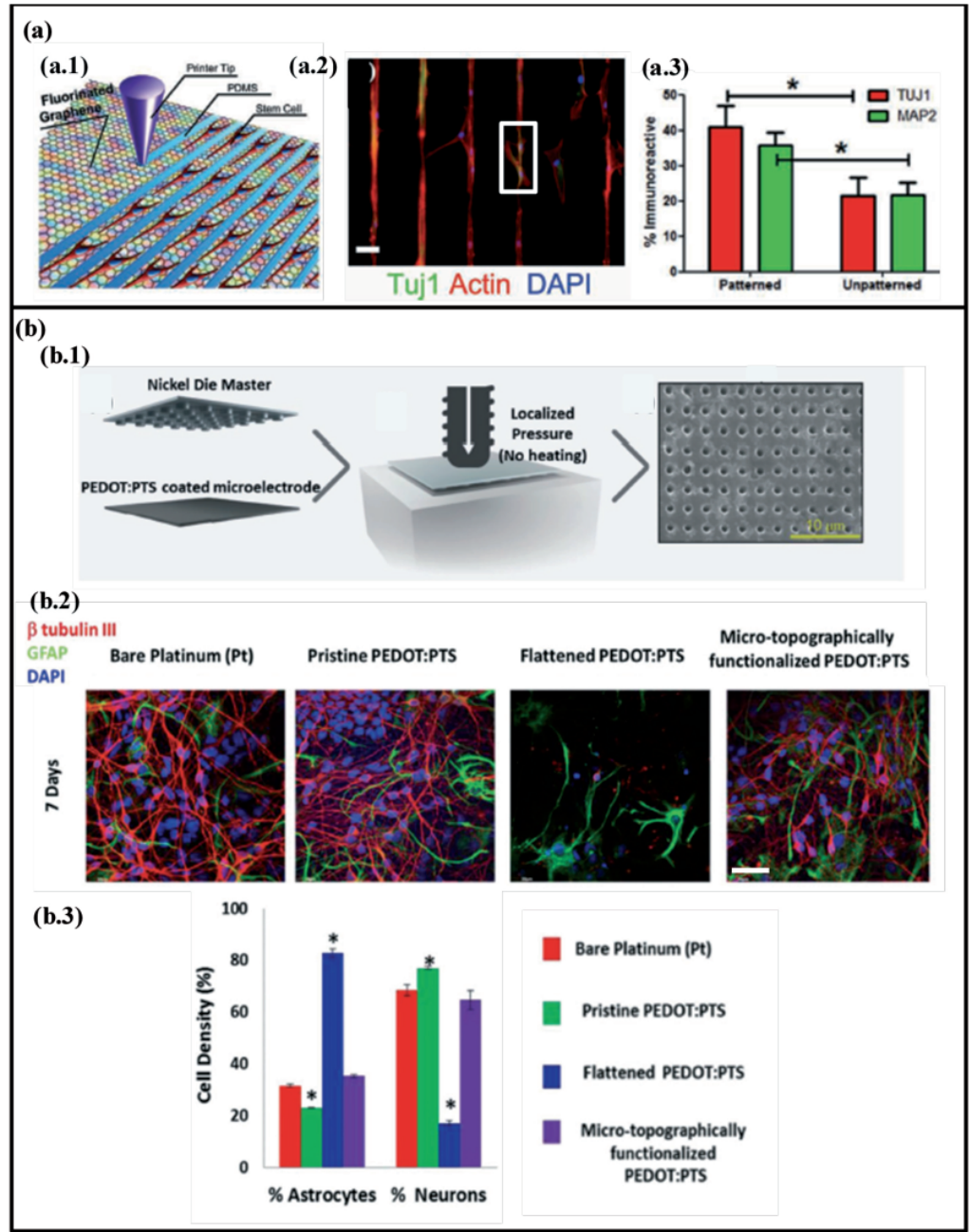

3. irudia. Mikrotxantiloien aplikazioak biomedikuntzan: (a.1) Grafenozko filmetan PDMS mikrotxantiloiak sortzeko prozesuaren adierazpen grafikoa. (a.2) Zelula mesenkimalen grafeno fluoratu zutabeetako itsaspen-selektiboa, F-actin (gorria) eta Tuj1(berdea) markatzaile neuralen bidez adierazia (eskala barra $=50 \mu \mathrm{m}$ ). (a.3) Tuj1 eta MAP2 markatzaileen ehunekoak mikrotxantiloiak daramatzaten eta ez daramatzaten gainazaletan [20]. (b.1) Presio lokalizatuzko inpresioaren adierazpen grafikoa. (b.2.) Zelulen populazioak nahasian zazpi egunetako hazkuntzaren ondoren platinozko elektrodoan, PEDOT:PTS-n, PEDOT:PTS lauan eta mikrotopografia bidez funtzionalizatutako PEDOT:PTS elektrodoan. Neuronak anti $\beta$-tubulin III bidez irudikatzen dira (gorriz), astrozitoak berriz anti-GFAP bidez (berdez) eta nukleoak DAPI bidez (urdinez) (eskala barra azken irudian $20 \mu \mathrm{m}$ ). (b.3) Elektrodoen gainazal mota ezberdinetan itsasten diren astrozito eta neurona dentsitateen ehunekoak [23]. 


\subsection{Integrazioa hobetzen duten mikroegituratutako inplanteen gainazalak}

Gaur egun, badira gaixoetan ezartzen diren zenbait aparailu mediko, adibidez, taupada-markagailuak, glukosa-sentsoreak edo artikulazioak ordezkatzeko protesiak. Horiek guztiek mundu osoan zehar urtero gaixo askoren bizi-kalitatea hobetzen dute. Haietan, gainazaleko materialaren, gailuaren tamainaren eta kontaktu denboraren arabera, gailuaren integrazioa gutxituko duten erreakzio fibrotikoak sor daitezke, eta horiek, era berean, gailuaren inguruan orbain-ehunez eginiko kapsula bat sortzea eragingo dute. Ehun mota horren ondorioz, gailuaren funtzioa eta bizitza asko murrizten dira, eta ehun ostalarian kalte handiak sor daitezke. Gainera, muturreko kasuan, infekzioa eragin eta inplantea ateratzeko ebakuntza egin behar izaten da, horrek gaixoarentzat dakarren arriskuarekin eta osasun-sistemarentzat den gastuarekin. Hori dela eta, ezarritako gailuaren onarpena eta funtzionamendua hobetzeko eta erreakzio fibrotikoak gutxitzeko, funtsezkoa da ehunen eta biomaterialaren arteko interakzioak hobeto kontrolatzea [21].

Hala, ikerketa ugarik adierazi dute inplantearen gainazalaren diseinu egokiarekin posible dela haien portaera hobetzea. Gainazal lauekin konparatuta, jakina da zimurtasun apur bat dutenek integrazio handiagoa erakusten dutela, enkapsulazio fibrotikoa gutxitzen dutela eta inplantearen materiala integratuago dagoela inguruko ehunean. Adibidez, frogatu da inplantatutako neuroelektrodoen inguruan orbain-ehun kapsula bat ez sortzeko, astrozitoen aldean neuronen itsaspena bultzatzeko, ondorengo gliosia (zelula glialen hazkuntza) saihesteko, ehunen hantura gutxitzeko eta epe luzera gailuaren egonkortasuna lortzeko, erabilgarriak direla gainazaleko topografia funtzionalizatuzko elektrodoak. Horrelako gainazaleko topografia edo txantiloiak lortzeko, elektrodoari Poli $(3,4-$ Etilendioxitiofenoa):P-Tolueno Sulfonatoa (PEDOT:PTS) estaldura ematen zaio, eta presio lokalizatuzko inpresioa erabiltzen da. Hala, mikrotxantiloi horiekin astrozitoen itsaspena gutxitzen da, eta neuronena, aldiz, handitu egiten da (ikus 3.(b) irudia). Gainera, hantura txikitzea ere lortzen da [23].

\subsection{Zeluletan oinarritutako biosentsoreak}

Zeluletan oinarritutako biosentsoreek zelulak elementu sentikor gisa erabiltzen dituzte. Horiek, inguruneko aldaketak prozesagarriak diren seinale bihurtzen dituzte. Zelulak elementu sentikorrak izanik, errezeptoreek proteina seinalizatzaileak eta entzimak bezalako sentsore-molekularrak sor ditzakete. Sentsore-molekular horiek beren berezko egoeran zeluletan aurkitzen dira, eta hori dela eta, zeluletan oinarritutako biosentsoreek sentsore-molekular arrunten aldean abantaila bat dute: sentsore-molekularrak 
Mikrotxantiloien fabrikazioa eta haien aplikazioak biomedikuntzan

zeluletan oinarritutako biosentsoreetan habitat naturalean daude; sentsoremolekular arruntak soilik hartuta, aldiz, beren ingurune naturalean ez daudenez, haien kaltetze erraza arazo handia izaten da [11]. Esaterako, proteinak, sentsore-molekular bezala, haiek soilik hartuta, inguruneko aldaketen ondorioz, desnaturalizatu eta degradatu egiten dira, eta horrek sentsoreen afinitatean eta zehaztasunean eragiten du [3]. Beraz, zelulek berek sentsore-molekularrentzat erlatiboki egonkorra den ingurunea eskaintzen dute, eta hori dela eta, zeluletan oinarritutako biosentsoreek errendimendu handiagoa dute sentsore-molekularretan oinarritutakoek baino.

Gainera, biosentsoreetan mikrotxantiloiak erabiltzen badira, zelulak era kontrolatuan egitura zehatzetan ezar daitezke, eta horrela, zeluletan oinarritutako sentsoreen etekina handitzen da. Elementu sentikor gisa zelula mota guztien artean, bereziki erabilgarriak dira elektrikoki kitzika daitezkeen zelulak, adibidez, neuronak. Izan ere, zelulen aktibitatea monitoriza daiteke potentzial elektriko elektrozelularra elektrodo batekin bilduz. Hala, neuronetan konkretuki, ingurunearen aldaketek eragite potentzial elektriko horretan aldaketak sortzen dituzte eta, beraz, neuronak, adibidez, drogak eta toxinak detektatzeko erabil daitezke. Hori burutzeko, biosentsoreetan neuronen gainazaleko posizioaren zehaztasuna kritikoa da. Orain arte, neuronak dentsitate altuan ezartzen ziren elektrodoan, eta horrela haien itsastea eta seinalea jasotzea ziurtatzen ziren, baina zehaztasuna ere galtzen zen. Neuronen biosentsoreetan mikrotxantiloiak erabiliz, berriz, neuronak elektrodoan era egokian ezartzen dira, eta emaitza hobeak lor daitezke. Kasu horretan, mikrotxantiloi horiek egiteko mikrokontaktuzko inpresioa erabili da Poli-L-lisina materialean [3].

Hala, zeluletan oinarritutako sentsoreek erabilgarritasun handia izan dute medikamentuen bilaketan, antigorputzen aukeraketan, toxinen, patogenoen eta ingurumenerako kaltegarriak diren beste zenbait substantziaren detekzioan eta diagnostiko klinikoetan [11]. Hala ere, azken aldian, arlo horrek aurrerapauso handiak eman dituen arren, oraindik badira konpondu gabe dauden zenbait alderdi; horien artean, nola mantendu zelulen aktibitatea, nola tamainaz txikitu sentsoreak eta nola aukeratu zelula mota egokiena [3].

\section{GAUZATUTAKO IKERKETA-LANA}

Gai honi lotuta Biomaterial Polimerikoen Zientzia eta Ingeniaritza ikerketa-taldean (ZIBIO) mikrotxantiloietan zelulen itsaskortasunari buruzko ikerketa lan bat eraman dugu aurrera. Jorratutako proiektuaren helburu nagusia zelulen itsaspen selektiboa eta lerrokatzea lortzea izan da, eta horretarako, gainazal polimerikoetan burutu dira mikrotxantiloi polimerikoak 3D inprimaketaren bidez. 
Aurreko helburua lortzeko, honako bi estrategia nagusi hauek jorratu dira. Lehenengoan, zelulak itsatsiko ez diren substratu baten gainean (hemendik aurrera, substratu-negatiboa) zelula-itsaspena sustatuko duen geometria ezberdinetako mikrotxantiloiak inprimatu dira. Bigarrenean, aldiz, alderantzizko bidea jarraitu da; hau da, zelula-itsaspena sustatuko duen substratu baten gainean (hemendik aurrera. substratu-positiboa) zelulak itsastea saihestuko duten geometria ezberdineko mikrotxantiloiak inprimatu dira.

Bi estrategia horiek jorratzeko, azterketa bibliografikoa egin ondoren material egokienak aukeratu dira. Lehenengo estrategian, zelulak itsatsiko ez diren polifluorurozko binilidenoa (PVDF; Pisu Molekularra $\left(\mathrm{M}_{\mathrm{w}}\right)$ : $180.000 \mathrm{~g} / \mathrm{mol}$; Sigma-Aldrich) film negatibo baten gainean ikerketa taldean sintetizatzen den poli-L-laktida-Dopamina (PLLA-Dopa) [24] polimero positiboa inprimatu da. Kasu horretan, PVDF polimeroaren ezaugarri hidrofoboa eta polidopaminaren ezaugarri itsaskorra dela eta [25], espero da zelulak soilik PLLA-Dopa gainean itsatsiko direla. Bigarren estrategian, aldiz, itsaskorra den polidopaminaz estalitako poli-L-laktidazko (PLLA) film positiboan, itsaskortasuna saihestuko duen silikona (Silcoferm S; Silikon Dichtstoff-41 dunkelbraun; PCI) inprimatu da.

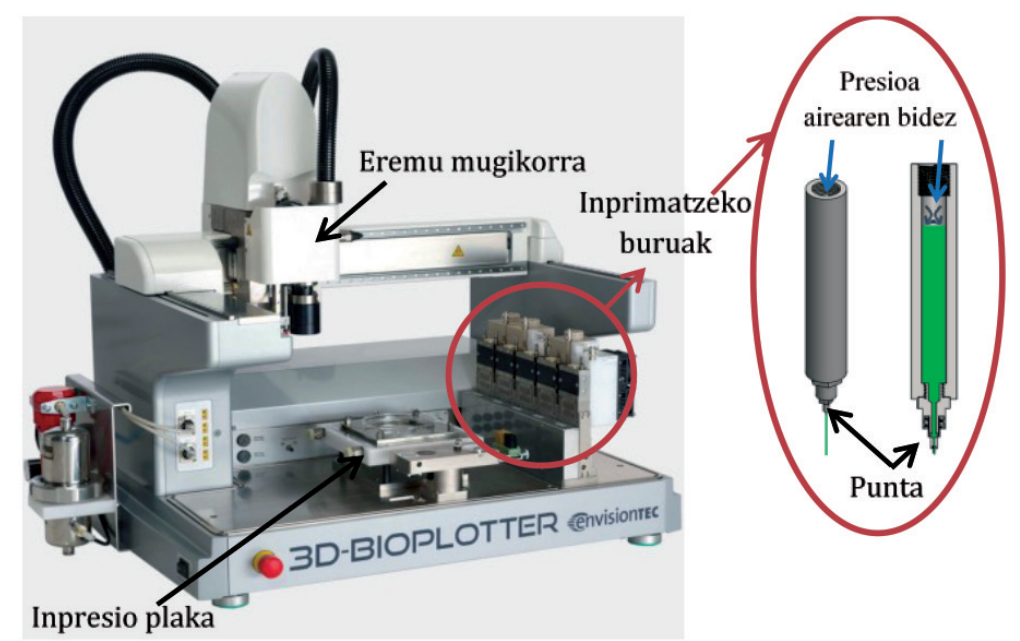

4. irudia. EnvisionTEC GmbH etxeko 3D-Bioplotter-aren atalak.

Gainera, lan horretako mikrotxantiloi guztiak 3D inpresioa edo fabrikazio-gehigarria delako teknikaren bidez ekoitzi dira, aurretik aipatutako abantailak direla eta. Alemaniako EnvisionTEC GmbH etxeko Developer Series modeloko 3D-Bioplotter makina erabiliz (ikus 4. irudia). Hain zuzen ere, fabrikazio-gehigarriaren barneko teknologia guztien artetik, estrusio bidezko inprimaketa (Extrusion Based Printing, EBP) erabiltzen du makina 
horrek, eta hala, zehaztasun, errepikagarritasun eta egonkortasun handiko mikrotxantiloiak lortu dira.

Bi bideetan, 5.(a) irudian ikus daitezkeenak bezalako hiru geometria ezberdineko mikrotxantiloiak egin dira: zutabe artekatuak, sareak eta irloteak, geometria ezberdinetan zelulek duten portaera ikusteko. Gainera, material bakoitzaren inpresio-parametro optimoak ere lortu dira, eta mikroskopio optiko (EVOS XL Core) bidez mikrotxantiloien argazkiak atera dira (ikus 5.(b) irudia). Ondoren, zenbait programa fotografikoren bidez (ImageJ) mikrotxantiloien neurri errealak lortu dira. Amaitzeko, behin mikrotxantiloi optimoak ditugunean, haietan HeLa motako zelulak ezarri dira. Izan ere, bibliografian zelula mota hau in vitro erabiltzen den eredu zelular onartua da. Jarraian, horien kokapen zehatza aztertu da alderantzikatutako fluoreszentzia mikroskopio (Nikon eclipse Ts2) baten bidez. Horretarako, aurretik zelulen nukleoa eta zitoeskeletoa, DAPI (urdina) eta rodamina-faloidinaz (gorria) tindatu dira, hurrenez hurren.

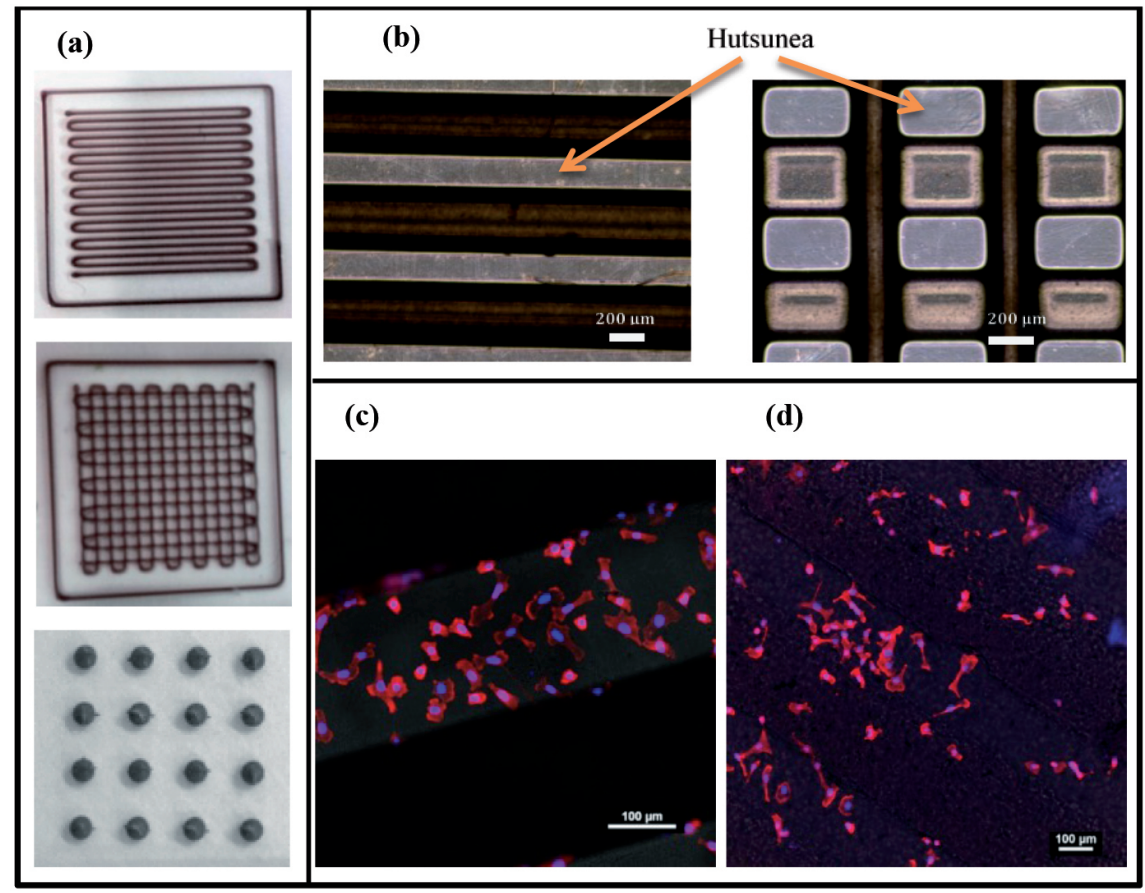

5. irudia. (a) Hiru geometria ezberdineko silikonazko mikrotxantiloiak: zutabe artekatuak, sareak eta irloteak. (b) Mikroskopio optikoz ateratako mikrotxantiloien argazkiak. (c) Silikonazko mikrotxantiloietan zelulen kokapen selektiboa (gorriz zelulen zitoeskeletoa eta urdinez nukleoa). (d) PLLA-Dopa-zko mikrotxantiloietan zelulen ezarpena, ez da ezarpen selektiboa lortu (gorriz zelulen zitoeskeletoa eta urdinez nukleoa). 
Artekatutako zutabe itxurako mikrotxantiloiei dagokienez, emaitzetan ikusten da proliferazio-prozesu egokia jarraitzen bada polidopaminaz estalitako PLLA substratuan HeLa zelulak ondo itsatsi eta hazten direla. Gainera, ez dira zelulak aurkitzen silikonazko zutabeetan (ikus 5.(c) irudia). Horrek adierazten du helburu den zelulen itsaspen selektiboa lortu dela mikrotxantiloi horretan. Aldiz, substratu gisa PVDF polimeroa eta PLLA-Dopaz inprimaturiko zutabeak dituen mikrotxantiloia erabiliz, ez da horrelako emaitzarik ikusi. Kasu horretan, HeLa zelulen itsaspena eta proliferizazioa berdin gertatu da substratuan eta zutabeetan. Beraz, esan daiteke helburu den itsaspen selektiboa ez dela lortu eta aukeratutako materialak ez direla egokiak itsaspen selektiboa bermatzeko (ikus 5.(d) irudia). Beste geometrien kasuan, antzeko emaitzak lortu ziren.

\section{ONDORIOAK}

Ondorioz, aipatu den guztiagatik mikrotxantiloiak hainbat aplikazio ezberdinetan erabilgarriak direla ikusi da, eta etorkizunean oraindik erabilpen handiagoa izango dutela aurreikus daiteke. Hori dela eta, haien fabrikazio-tekniken eta propietateen ezagutza izatea komenigarria da. Esaterako, gure ikerketan frogatu da zelulen itsaspen-selektiboa lortzeko baliagarriak direla, baldin eta materialak ondo aukeratzen badira. Hala ere, oraindik erronka handia da mikrotxantiloietan zelulek guk nahi dugun portaera izatea eta zelula mota bakoitzerako material eta geometria egokienak zeintzuk izango diren zehaztea. Dena den, behin hori lortuta, aplikazio biomedikoetarako oso erabilgarriak izango direla uste da.

\section{ESKER ONAK}

Eskerrak, Eusko Jaurlaritzako Hezkuntza, Hizkuntza Politika eta Kultura Sailari eta ZIBIO taldeari emaniko sostenguagatik (erref. IT-927).

\section{BIBLIOGRAFIA}

[1] CHATE G. P., KALE N. R., KHOBRAGADE V., RAHANE C., CALDERÓN M., BANERJEE S. S. eta KHANDARE J. J. 2018. «Selective cell isolation by transferrin functionalized silane-carbon soot mediated superhydrophobic micropatterns». Advanced Materials Interfaces, 5, 1701581.

[2] LEE H. J., KIM D. N., PARK S., LEE Y. eta KOH W. 2011. «Micropatterning of a nanoporous alumina membrane with poly(ethylene glycol) hydrogel to create cellular micropatterns on nanotopographic substrates». Acta Biomaterialia, 7, 1281-1289. 
Mikrotxantiloien fabrikazioa eta haien aplikazioak biomedikuntzan

[3] WEN-WEN L., ZHEN-LING C. eta XING-YU J. 2009. «Methods for cell micropatterning on two-dimensional surfaces and their applications in biology». Chinese Journal of Analytical Chemistry, 37, 943-949.

[4] LI G., ZHAO X., ZHAO W., ZHANG L., WANG C., JIANG M., GU X. eta YANG Y. 2014. «Porous chitosan scaffolds with surface micropatterning and inner porosity and their effects on Schwann cells». Biomaterials, 35, 8503-8513.

[5] YANG C., LIAO T., SHUAI H., SHEN T., YEH J. A. eta CHENG C. 2012. «Micropatterning of mammalian cells on inorganic-based nanosponges». Biomaterials, 33, 4988-4997.

[6] VALDESPINO-GÓMEZ V. M., VALDESPINO-CASTILLO P. M. eta VALDESPINO-CASTILLO V. E. 2014. «Estrategias para la regeneración de tejidos: células, inductores bioquímicos, bionanomateriales y bioconstrucciones. Alcances clínicoquirúrgicos». Cirugía y Cirujanos, 82, 578-589.

[7] FABRES C. 2010. «Técnicas del futuro: Ingeniería de tejidos y usos de células madre en medicina reproductiva». Revista Médica Clínica Las Condes, 21, 488-493.

[8] LAURENCIN C. T, ASHE K.M., HENRY N., KAN H. M. eta LO K. W-H. 2014. «Delivery of small molecules for bone regenerative engineering: preclinical studies and potential clinical applications». Drug Discovery Today, 19, 794-800.

[9] CHO W. K., KONG B., PARK H. J., KIM J., CHEGAL W., CHOI J. S. eta CHOI I. S. 2010. «Long-term stability of cell micropatterns on poly((3(methacryloylamino)propyl)-dimethyl(3-sulfopropyl)ammonium hydroxide)patterned silicon oxide surfaces». Biomaterials, 31, 9565-9574.

[10] WEN-WEN L., ZHEN-LING C. eta XING-YU J. 2009. «Methods for cell micropatterning on two-dimensional surfaces and their applications in biology». Chinese Journal of Analytical Chemistry, 37, 943-949.

[11] YAP F.L. eta ZHANG Y. 2007. «Protein and cell micropatterning and its integration with micro/nanoparticles assembly». Biosensors and Bioelectronics, 22, 775-788.

[12] FALCONNET D., CSUCS G., GRANDIN H. M. eta TEXTOR M. 2006. «Surface engineering approaches to micropattern surfaces for cell-based assays». Biomaterials, 27, 3044-3063.

[13] ELLOUMI-HANNACHI I., MAEDA M., YAMATO M. eta OKANO T. 2010. «Portable microcontact printing device for cell culture». Biomaterials, 31, 8974-8979.

[14] HALE P. S., KAPPEN P., BRACK N., PRISSANAROON W., PIGRAM P. J. eta LIESEGANG J. 2006. «Micropatterning of fluoropolymers». Applied Surface Science, 252, 2217-2228.

[15] ZHAO Y., TRUCKENMULLER R., LEVERS M., HUA W.-S., BOER J. eta PAPENBURG B. 2017. «High-definition micropatterning method for hard, stiff and brittle polymers». Materials Science and Engineering C, 71, 558-564. 
$\underline{\text { Eider Aldalur,Jose-RamonSarasua, Aitor Larrañaga,JoneM.Ugartemendia }}$

[16] ITOGA K., KOBAYASHI J., YAMATO M., KIKUCHI A. eta OKANO T. 2006. «Maskless liquid-crystal-display projection photolithography for improved design flexibility of cellular micropatterns». Biomaterials, 27, 30053009.

[17] RODRIGUEZ-EMMENEGGER C., PREUSS C. M., YAMEEN B., POPGEORGIEVSKI O., BACHMANN M., MUELLER J. O., BRUNS M., GOLDMANN A. S., BASTMEYER M. eta BARNER-KOWOLLIK C. 2013. "Controlled cell adhesion on poly(dopamine) interfaces photopatterned with non-fouling brushes». Advanced Materials, 25, 6123-6127.

[18] KARP J. M., YEO Y., GENG W., CANNIZARROB C., YAN K., KOHANE D. S., VUNJAK-NOVAKOVIC G., LANGER R. S.eta RADISIC M. 2006. «A photolithographic method to create cellular micropatterns». Biomaterials, 27, 4755-4764.

[19] SZOJKAA A., LALHA K., ANDREWSA S. H. J., JOMHAA N. M., OSSWALDA M. eta ADESIDAA A. B. 2017. «Biomimetic 3D printed scaffolds for meniscus tissue engineering». Bioprinting, 8, 1-7.

[20] WANG Y., LEE W. C., MANGA K. K., ANG P. K., LU J., LIU Y. P., LIM C. T. eta LOH K. P. 2012. «Fluorinated graphene for promoting neuro-induction of stem cells». Advanced Materials, 24, 4285-4290.

[21] MAJD H., SCHERER S. S., BOO S., RAMONDETTI S., CAMBRIDGE E., RAFFOUL W., FRIEDRICH M., PITTET B., PIOLETTI D., HINZ B. eta PIETRAMAGGIORI G. 2015. «Novel micropatterns mechanically control fibrotic reactions at the surface of silicone implants». Biomaterials, 54, 136147.

[22] TANG Q., PIARD C., LIN J., NAN K., GUO T., CACCAMESE J., FISHER J. eta CHEN Y. 2018. «Imaging stem cell distribution, growth, migration, and differentiation in 3-D scaffolds for bone tissue using mesoscopic fluorescence tomography». Biotechnology and Bioengineering, 115, 257-265.

[23] VALLEJO-GIRALDO C., KRUKIEWICZ K., CALARESU I., ZHU J., PALMA M., FERNANDEZ-YAGUE M., MCDOWELL B. W., PEIXOTO N., FARID N., O'CONNOR G., BALLERINI L., PANDIT A. eta BIGGS M. J. P. 2018. «Attenuated glial reactivity on topographically functionalized poly(3,4-ethylenedioxythiophene):p-toluene sulfonate (PEDOT:PTS) neuroelectrodes fabricated by microimprint lithography». Small, 14, 1800863.

[24] SADABA N., SALSAMENDI M., CASADO N., ZUZA E., MUÑOZ J., SARASUA J-R., MECERREYES D., MANTIONE D., DETREMBLEUR C. eta SARDON H. 2018. «Catechol end-functionalized polylactide by organocatalyzed ring-opening polymerization». Polymers, 10, 155.

[25] LIU Y., AI K. eta LU L. 2014. «Polydopamine and its derivative materials: synthesis and promising applications in energy, environmental, and biomedical fields». Chemical Reviews, 114, 5057-5115. 